\title{
Moisture adsorption characteristics of ginger slices
}

\author{
Características de adsorção de umidade de gengibre em fatias
}

\author{
Joseph ALAKALI ${ }^{2}$, Simon Verlumun IRTWANGE ${ }^{1 *}$, Adesola SATIMEHIN ${ }^{1}$
}

\begin{abstract}
The moisture adsorption characteristics of dried ginger slices was studied to determine the effect of storage conditions on moisture adsorption for the purpose of shelf life prediction, selection of appropriate packaging materials, evaluate the goodness-of-fit of sorption models, and determine the thermodynamics of moisture adsorption for application in drying. There was a highly significant effect ( $\mathrm{p} \leq 0.05)$ of water activity $\left(\mathrm{a}_{\mathrm{w}}\right)$, temperature, and pre-treatment on the equilibrium moisture content (EMC) of the dried ginger slices. At constant $\mathrm{a}_{\mathrm{w}}$, the EMC decreased as temperature increased. The EMC of all samples increased as the $\mathrm{a}_{\mathrm{w}}$ increased at constant temperature. The sorbed moisture of the unpeeled ginger slices was higher than the peeled while those of unblanched samples were higher than the blanched. Henderson equation allows more accurate predictions about the isotherms with the lowest \%RMS, and therefore, it describes best the adsorption data followed by GAB, Oswin, and Halsey models in that order. The monolayer moisture generally decreased with temperature for all samples. The isosteric heat decreased with moisture content approaching the asymptotic value or the latent heat of vaporization of pure water $\left(\Delta \mathrm{H}_{\mathrm{st}}=0\right) \mathrm{while}$ the entropy of sorption was observed to increase with moisture content.

Keywords: sorption models; thermodynamics; water activity; ginger slices.
\end{abstract}

\section{Resumo}

As características da adsorção de umidade de amostras de gengibre secas foram estudadas para se determinar o efeito das condições de armazenamento com o propósito de se prever a vida de prateleira ou validade, a seleção de materiais apropriados para empacotamento, avaliar a bondade de ajuste dos modelos de sorção e determinar a termodinâmica da adsorção de umidade para aplicação em secagem. Houve um efeito significativo $(\mathrm{p} \leq 0,05)$ da atividade de água, da temperatura e do pré-tratamento sobre o teor de umidade de equilíbrio higroscópico das amostras de gengibre secas. Sob atividade de água constante $\left(\mathrm{a}_{\mathrm{w}}\right)$, o teor de umidade de equilíbrio higroscópico (CEM) diminuiu com o aumento da temperatura. $\mathrm{O}$ teor de umidade de equilíbrio higroscópico de todas as amostras aumentou com o aumento da atividade de água, sob temperatura constante. A umidade de sorção das amostras de gengibre com casca foi maior do que a das amostras de gengibre sem casca enquanto que a das amostras de gengibre não escaldo com e sem casca foi maior do que a das amostras de gengibre escaldado com e sem casca. A equação de Henderson permite previsões mais exatas das isotermas com o menor valor de média quadrática percentual (\%RMS) e, portanto, descreve melhor os dados de adsorção dos modelos de Guggenheim Anderson De-Boer (GAB), Oswin e Halsey, nesta ordem. A umidade de monocamada, em geral, diminuiu com a temperatura em todas as amostras. O calor isostérico diminuiu quando o teor de umidade se aproximou do valor assimptótico ou o calor latente de vaporização da água pura $\left(\Delta \mathrm{H}_{\text {st }}=0\right)$, enquanto que a entropia de sorção aumentou com o teor de umidade.

Palavras-chave: modelos de sorção; termodinâmica; atividade de água; amostras de gengibre.

\section{Introduction}

Ginger (Zinziber officinale) was one of the earliest oriental species known in Europe in the $9^{\text {th }}$ century. In the $13^{\text {th }}$ century, it was introduced to East Africa by the Arabs. In West Africa and other parts of the tropics, it was introduced by the Portuguese in the $16^{\text {th }}$ century (KOCHHAR, 1981). India remains the world's largest producer of ginger accounting for more than $50 \%$ and Nigeria is one of the top producers.

Ginger is required on a daily basis. In most households, it is used as local medicine and as spice for flavoring and seasoning (AERLS, 1987). The ginger used for commercial purposes is the dried rhizome. It is used in the raw fresh state in small quantities. Kochhar (1981) reported that the methods of preparing ginger vary in different producing countries. The important grades of dried ginger recognized in the spice trade market are the scrapped or peeled ginger known as uncoated, and the unscrapped or unpeeled ginger. In some countries, the rhizomes are plunged into boiling water for a few minutes (scalded) and then dried. Since the ginger available in the international market is in the dried form, it is necessary to study moisture sorption characteristics of dried ginger. Moisture sorption data is useful for shelf life prediction and selection of appropriate packaging materials. It also serves as useful information for determining the interaction of water, food material, and the thermodynamics of the process (CENKOWSKI; JAYAS; HAO, 1992; ARIAHU; KAZE; ACHEM, 2006).

The objectives of this work are to study the effect of storage conditions on moisture adsorption characteristics of ginger

Recebido para publicação em 14/8/2007

Aceito para publicação em 28/10/2008 (002760)

${ }^{1}$ Department of Agricultural and Environmental Engineering, University of Agriculture, Makurd, Nigeria, E-mail: svirtwange@yahoo.com

${ }^{2}$ Department of Food Science and Technology, University of Agriculture, Makurdi, Nigéria

${ }^{*}$ A quem a correspondência deve ser enviada 
slices to evaluate the goodness-of-fit of sorption models and to determine the thermodynamics of moisture adsorption of ginger slices.

\section{Materials and methods}

\subsection{Sample preparation}

Yellow ginger rhizomes were purchased from a local market in Makurdi, Nigeria. The ginger rhizomes were thoroughly washed in tap water and divided into three portions. One portion was peeled with a stainless steel knife and cut into slices about 2-3 mm thick. The peeled slices were divided into two parts. One part was blanched at $65^{\circ} \mathrm{C}$ for 3 minutes in a laboratory bath. The unpeeled portion was also cut into $3 \mathrm{~mm}$ slices and divided into two parts. One part was blanched in $65^{\circ} \mathrm{C}$ for 3 minutes using a laboratory bath. All slices were dried in an electric oven (Model T12H Genlab, England) at $65^{\circ} \mathrm{C}$ for 48 hours to produce Peeled Ginger Slices (PGS), PeeledBlanched Ginger Slices (PBS), Unpeeled Ginger Slices (UGS), and Unpeeled-Blanched Ginger Slices (UBS). The four samples were further dried in desiccators over concentrated sulphuric acid for seven days. The samples were sealed in polythene bags and kept in separate airtight containers to be used in the sorption studies.

\subsection{Determination of moisture adsorption isotherms}

The moisture adsorption of the ginger slices subjected to different pre-treatment were determined gravimetrically (MOK; HETTIARACHCHY, 1990). A split plot in Randomized Complete Block Design (RCBD) comprising of four samples (PGS, PBS, UGS, and UBS), four temperatures (20, 30, 40, 36 and $50{ }^{\circ} \mathrm{C}$ ), and seven water activities ranging from 0.371 to 0.939 were used. The water adsorption characteristics of ginger slices were determined by exposing the samples to atmospheres of known relative humidities from 37.1 to $93.7 \%$.

Sulphuric acid solutions required to produce the desired humidities were pippeted into a $500 \mathrm{~mL}$ capacity airtight plastic containers. (WEAST; ASTLE, 1989). Triplicate samples, $0.5 \mathrm{~g}$ each, were weighed in crown corks which were placed on wire gauze above the solution. The plastic containers were covered with lids and allowed to equilibrate to selected temperatures $20,30,40$ and $50{ }^{\circ} \mathrm{C}$, respectively in the Gallenkamp Incubator (Model INF 600.010R). The samples were removed and weighed at 48 hours interval until three successive readings were each less than $0.5 \%$ of the previous 9 weights (SPIESS; WOLF, 1986).

\subsection{Moisture sorption models}

The moisture adsorption data of the samples was evaluated for goodness-of-fit using the Henderson, Guggenheim Anderson De-Boer, Oswin, and Halsey models. Henderson (1952) developed a model (Equation 1) describing the temperature effect on moisture sorption.

$1-\mathrm{a}_{\mathrm{w}}=\exp \left(-\mathrm{ATM}_{\mathrm{e}}^{\mathrm{B}}\right)$ where $\mathrm{A}$ and $\mathrm{B}=$ constants, $\mathrm{T}=$ temperature and $\mathrm{M}_{\mathrm{e}}=$ equilibrium moisture content. Rearranging Equation (1) we have (Equation 2):

$\operatorname{Ln}\left[-\ln \left(1-\mathrm{a}_{\mathrm{w}}\right)\right]=\ln (\mathrm{AT})+\mathrm{B} \ln \mathrm{M}_{\mathrm{e}}$

The GAB model according to Bizot (1983) and Van den Berg (MOK; HETTIARACHCHY, 1990) states that (Equation 3):

$\frac{M}{M_{o}}=\frac{G K a_{w}}{\left(1-K a_{w}\right)\left(1-k a_{w}+G K a_{w}\right)}$

where $\mathrm{G}$ and $\mathrm{K}=$ constants, $\mathrm{M}_{\mathrm{o}}=$ monolayer moisture content.

The Oswin model (OSWIN, 1946) is written in the form (Equation 4):

$M=A\left[\frac{a_{w}}{1-a_{w}}\right]^{B}$

where $\mathrm{A}$ and $\mathrm{B}$ are constants.

The modified Halsey equation (HALSEY, 1948) is as follows (Equation 5):

$M_{o}=\left[\frac{\exp A T+B}{-\ln \left(a_{w}\right)}\right]^{C}$

where $\mathrm{A}, \mathrm{B}$, and $\mathrm{C}$ are constants.

\subsection{Thermodynamics}

\section{Isosteric heat of sorption}

Chen and Lai (1990) described four methods of determining isosteric heat of agricultural products. These include the direct calorimetric measurement technique and calculation from the EMC data using BET, Othmer, and Clausius-Clapeyron equation. The Clausius-Clapeyron equation is widely used in sorption studies because of its theoretical basis (IGLESIAS; CHIRIFE, 1976; EZEIKE, 1988; WANG; BRENNAN, 1991; CENKOWSKI; JAYAS; HAO, 1992). At a constant amount of sorbed water, the Clausius-Clapeyron equation is expressed by Wang and Brennan (1991) and Cenkowski et al. (1992) as Equation (6):

$\ln a_{w}=\left(\frac{-\mathrm{D} H_{s t}}{R_{O}}\right) \frac{1}{T}+C_{s t}$

where $\mathrm{C}_{\mathrm{st}}$ is the constant of integration.

Equation (6) was used to calculate the isosteric heats of desorption. A least-squares regression analysis was performed to obtain the slope of the straight line representing $\ln \left(\mathrm{a}_{\mathrm{w}}\right)$ versus $1 / \mathrm{T}$.

A mathematical model which expresses the heat of sorption as a function of moisture was developed by Gallagher (1951), and it is commonly cited in the literature (EZEIKE, 1988; CENKOWSKI; JAYAS; HAO, 1992; SATIMEHIN; EZEIKE, 2002). The equation is given as follows (Equation 7): 
$\Delta H_{s t}=\Delta H_{o} \exp \left[-\frac{M}{M_{c h}}\right]$

where $\Delta \mathrm{H}_{\mathrm{o}}$ is the isosteric heat of sorption of the first molecule of water in the food $(\mathrm{kJ} / \mathrm{mol})$ and $\mathrm{M}_{\mathrm{ch}}$ is the characteristic moisture content ( $\mathrm{g} \mathrm{H}_{2} \mathrm{O} .100 \mathrm{~g}^{-1}$ solid) of the food material; it is the moisture content at which the net isosteric heat of desorption was reduced by $63 \%$ (KIRANOUDIS et al., 1993). Equation (7) was fitted to the data for $\Delta \mathrm{H}_{\text {st }}$ and moisture content $(\mathrm{M})$ by 15-least square non-linear analysis to obtain the values of $\Delta \mathrm{H}_{\mathrm{o}}$ and $\mathrm{M}_{\mathrm{ch}}$ for FSG, MSG, and CSG 16-samples.

\section{Entropy of sorption}

The entropy of sorption was derived from the Gibbs free energy of sorption and related to temperature (ARIAHU; KAZE; ACHEM, 2006; RIZVI, 1995) as follows (Equation 8):

$\Delta \mathrm{G}^{\mathrm{o}}=\Delta \mathrm{H}_{\mathrm{st}}-\mathrm{T} \Delta \mathrm{S}^{\mathrm{o}}$

where $\Delta \mathrm{G}^{\mathrm{o}}$ is Gibbs free energy $\left(\mathrm{kJ} \cdot \mathrm{mol}^{-1}\right)$ and $\Delta \mathrm{S}^{\circ}$ is the isosteric entropy of sorption $(\mathrm{kJ} / \mathrm{mol}-\mathrm{K})$.

According to Rizvi (1995), Gibbs free energy is related to water activity as follows (Equation 9):

$\Delta \mathrm{G}^{\mathrm{o}}=\mathrm{RT} \ln \left(\mathrm{a}_{\mathrm{w}}\right)$

From Equations (8 and 9), it follows that (Equation 10):

$\ln \left(a_{w}\right)=\frac{-\Delta S^{o}}{R}+\frac{\Delta H_{s t}}{R T}$

The $\Delta S^{\circ}$ values were determined from the intercept coefficient derived from least square regression of the plot of $\ln \left(\mathrm{a}_{\mathrm{w}}\right)$ versus $1 / \mathrm{T}$ at constant moisture content.

\subsection{Statistical analysis}

The GAB model was evaluated using non-linear regression while the Henderson, Oswin, and Halsey models were evaluated by linearized forms of the equations using SPSS for windows version 6.0. The goodness-of-fit of the models were evaluated using the percent root mean square of error (\%RMS) as prescribed by Wang and Brennan (1991) (Equation 11):

$\% R M S=\sqrt{\sum \frac{\left(\frac{M_{o b}-M_{e s t}}{M_{o b}}\right)^{2}}{n}}$

where $\mathrm{M}_{\mathrm{ob}}=$ experimental values; $\mathrm{M}_{\text {est }}$ = predicted values; and $\mathrm{n}=$ number of observations.

\section{Results and discussion}

The effect of processing methods, temperature, and water activity on EMC is presented in Table 1 while the analysis of variance (ANOVA) is summarized in Table 2. Mean values of Equilibrium Moisture Content (EMCs) were plotted against water activities to obtain the moisture sorption isotherms. Moisture sorption isotherms of the samples at 20,30,40, and
$50{ }^{\circ} \mathrm{C}$ are presented in Figure 1. The isotherms exhibited J shapes described as type III in the isotherm classification (IGLESIAS; CHIRIFE, 1982). Type III isotherm is typical of foods high in carbohydrates and salts (ARIAHU; KAZE; ACHEM, 2006). The analysis of variance (Table 2) shows highly significant processing methods, temperature, and $\mathrm{a}_{\mathrm{w}}$ effects.

Fishers Least Significant Difference (F-LSD)

- F-LSD ( $p=0.05$ ) of the difference between two processing methods means $=0.6060$;

- F-LSD ( $p=0.05)$ of the difference between two temperature means $=0.3922$; and

- F-LSD ( $\mathrm{p}=0.05$ ) of the difference between two water activity means $=0.8905$.

\subsection{Effect of temperature}

Figure 1 shows that at constant water activity $\left(\mathrm{a}_{\mathrm{w}}\right)$ equilibrium moisture content (EMC) decreased as temperature increased. At $\mathrm{a}_{\mathrm{w}}$ of 0.472 , EMC of PGS decreased from $7.20 \mathrm{gH}_{2} 0.100 \mathrm{~g}^{-1}$ solid at $20{ }^{\circ} \mathrm{C}$ to $3.80 \mathrm{gH}_{2} 0.100 \mathrm{~g}^{-1}$ solid at $50{ }^{\circ} \mathrm{C}$. Similar trend was observed for all other samples. This means that at any relative humidity ginger slices become less hygroscopic with an increase in temperature. Consequently, in an environment of constant relative humidity, it can absorb more moisture at lower than at higher temperatures. At constant moisture content, an increase in temperature caused lowering of isotherm curves which increased $\mathrm{a}_{\mathrm{w}}$ thereby making ginger slices more susceptible to microbial spoilage (ROCKLAND, 1969). Similar trends were reported for fish flour (LABUZA; KAANENE; CHEN, 1985), beans flour (MENKOV; DURAKOVA, 2005), and tropical fresh water crayfish (ARIAHU; KAZE; ACHEM, 2006).

A 2-tailed F-LSD test at the 5\% level of significance shows that in the case of UGS and UBS, the EMCs were found to be statistically different at all temperature levels. In the case of PBS, statistical difference was observed at 20 and $30^{\circ} \mathrm{C}$, but at 40 and $50{ }^{\circ} \mathrm{C}$ one and three mean comparisons, respectively, out of 21 indicated non-significance. In the case of PGS, statistical difference was observed at all temperature levels except for $50{ }^{\circ} \mathrm{C}$ at which two mean comparisons indicated non-significance.

\subsection{Effect of water activity}

Table 1 shows that the moisture content of the PGS increased as the water activity increased at constant temperature. The amount of water sorbed at $\mathrm{a}_{\mathrm{w}}$ below 0.805 was generally low for relatively large increase in water activity. This trend was observed for all other samples. This implies that the critical equilibrium relative humidity (ERH) of the dried ginger slices fall between 70 and $80 \%$ in the temperature range studied $\left(20-50{ }^{\circ} \mathrm{C}\right)$. Above this range, there will be an astronomical increase in the moisture adsorbed with relatively small increment in water activity indicating the region of rapid spoilage (LABUZA; KAANENE; CHEN, 1985).

A 2-tailed F-LSD test at the 5\% level of significance indicates that the EMCs were found to be statistically different at all $\mathrm{a}_{\mathrm{w}}$ levels for PBS except at the $\mathrm{a}_{\mathrm{w}}$ level of 0.371 , at which non- sig- 
Table 1. Effect of processing methods, temperature, and water activity on EMC of ginger slices.

\begin{tabular}{|c|c|c|c|c|c|c|c|c|}
\hline \multirow[t]{2}{*}{ Pre-treatment } & \multirow[t]{2}{*}{ Temperature $\left({ }^{\circ} \mathrm{C}\right)$} & \multicolumn{7}{|c|}{ Water activity $\left(\mathrm{a}_{\mathrm{w}}\right)$} \\
\hline & & 0.371 & 0.472 & 0.583 & 0.704 & 0.805 & 0.888 & 0.939 \\
\hline \multirow[t]{3}{*}{ Peeled Ginger Slice (PGS) } & 20 & 4.0 & 7.2 & 9.8 & 11.7 & 13.3 & 18.4 & 23.3 \\
\hline & 40 & 3.2 & 4.6 & 6.0 & 7.8 & 10.3 & 13.9 & 20.6 \\
\hline & 50 & 3.2 & 3.8 & 5.7 & 6.4 & 8.7 & 10.7 & 20.0 \\
\hline \multirow{2}{*}{$\begin{array}{l}\text { Unpeeled Ginger Slice } \\
\text { (UGS) }\end{array}$} & 20 & 4.2 & 7.7 & 10.9 & 11.9 & 13.6 & 18.8 & 24.4 \\
\hline & 50 & 3.4 & 5.2 & 8.6 & 9.8 & 11.2 & 16.3 & 20.3 \\
\hline \multirow{4}{*}{$\begin{array}{l}\text { Peeled-Blanched Ginger } \\
\text { Slice (PBS) }\end{array}$} & 20 & 3.8 & 6.7 & 8.5 & 11.1 & 13.0 & 17.9 & 21.5 \\
\hline & 30 & 3.5 & 5.0 & 6.7 & 10.0 & 11.3 & 14.9 & 21.0 \\
\hline & 40 & 3.2 & 4.1 & 5.9 & 9.7 & 10.3 & 13.7 & 21.0 \\
\hline & 50 & 3.0 & 3.8 & 4.3 & 8.3 & 8.8 & 10.4 & 20.0 \\
\hline $\begin{array}{l}\text { Unpeeled-Blanched } \\
\text { Ginger Slices (UBS) }\end{array}$ & 50 & 3.2 & 6.1 & 8.0 & 9.9 & 11.5 & 16.0 & 22.0 \\
\hline
\end{tabular}

${ }^{*}$ EMC values are means of three replications.

Table 2. Summary of ANOVA on effect of processing methods on EMC of ginger slices at various levels of water activity and temperature.

\begin{tabular}{lcccc}
\hline \multicolumn{1}{c}{$\begin{array}{c}\text { Source of } \\
\text { variation }\end{array}$} & $\begin{array}{c}\text { Degrees of } \\
\text { freedom }\end{array}$ & $\begin{array}{c}\text { EMC of ginger } \\
\text { slices }\end{array}$ & $5 \%$ & $1 \%$ \\
\hline Water activity & 6 & $532.85^{* *}$ & 2.66 & 4.01 \\
Pre-treatment & 3 & $21.05^{* *}$ & 3.16 & 5.09 \\
Error (a) & 18 & & & \\
Temperature & 3 & $81.59^{* *}$ & 2.744 & 4.094 \\
Interaction & 9 & $2.68^{\text {NS }}$ & 2.024 & 2.688 \\
Error (b) & 72 & & & \\
\hline **Highly significant $(\mathrm{p}=0.01) ;$ and ${ }^{\text {NSNon-significant. }}$ & &
\end{tabular}

${ }^{* *}$ Highly significant $(\mathrm{p}=0.01)$; and ${ }^{\text {NS} N o n-s i g n i f i c a n t . ~}$

nificance was observed in three out of six mean comparisons and at $\mathrm{a}_{\mathrm{w}}$ levels of $0.472,0.704$, and 0.939 . At each of these cases, one non-significance mean comparison was observed. In the case of UGS and PGS, the EMCs were statistically different at all $\mathrm{a}_{\mathrm{w}}$ levels except at 0.371 and 0.583 .

Whereas two out of six non-significance mean comparisons were observed for UGS at both $\mathrm{a}_{\mathrm{w}}$ levels. Three and one out of six non-significance mean comparisons, respectively, were observed for PGS. In the case of UBS, a statistical difference was observed between all EMCs at $\mathrm{a}_{\mathrm{w}}$ level of 0.888 , but three comparisons showed non-difference at $\mathrm{a}_{\mathrm{w}}$ levels of 0.371 and 0.939 , two at $\mathrm{a}_{\mathrm{w}}$ level of 0.472 , and one each at $\mathrm{a}_{\mathrm{w}}$ levels of $0.583,0.704$, and 0.805 .

\subsection{Effect of pre-treatment}

Figure 1 shows the typical effect of pretreatment on moisture adsorption of PGS, PBS, UGS, UBS samples. The graphs show that peeling and blanching have influence on moisture adsorption. The sorbed moisture of unpeeled ginger was higher than the peeled slices. The trend was the same in both blanched and unblanched samples. Naturally, it was expected that peeled ginger slices should be more hygroscopic due to the increased surface area of sorption and direct contact of the slices (without peels) with moisture. However, this work revealed that unpeeled ginger slices absorbed more moisture. This could be attributed to the high porosity of unpeeled ginger due to the presence of peels and the presence of pentosan in the peels since pentosan is known to be highly hygrophilic. Figure 1 also reveals that the moisture adsorption capacity of ginger was reduced by blanching. The sorbed moisture of blanched was lower than the unblanched samples of both peeled and unpeeled ginger slices. This could be due to gelatinization of starch molecules which may have blocked sorption sites thus reducing water adsorption. The sorbed moisture of the peeled blanched ginger slices was the lowest compared to all other samples. This indicates that peeled blanched ginger is more shelf stable.

A 2-tailed F-LSD test at the 5\% level of significance at all seven levels of $\mathrm{a}_{\mathrm{w}}$ and four levels of temperature representing 28 mean comparisons shows that between PGS and UGS 32.14\% of the mean comparisons were non-significant. Similarly, $75 \%$ nonsignificance was observed in the mean comparisons between PGS and PBS, 32.14\% between PGS and UBS, 25\% between UGS and PBS, $82.14 \%$ between UGS and UBS, and 21.43\% between PBS and UBS. The EMCs of the peeled ginger slices were generally lower than those of the unpeeled at the temperatures and water activities studied. At $40^{\circ} \mathrm{C}$ and water activity of

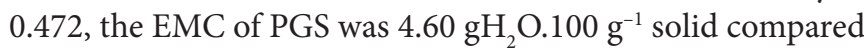
to $6.4016-\mathrm{gH}_{2} \mathrm{O} .100 \mathrm{~g}^{-1}$ solid for UGS. Similarly, the EMC of PBS was $4.10 \mathrm{gH}_{2} \mathrm{O} .100 \mathrm{~g}^{-1}$ solid compared to $6.10 \mathrm{gH}_{2} \mathrm{O} .100 \mathrm{~g}^{-1}$ solid of UBS. Similar trends were observed at all temperatures and water activities studied.

\subsection{Goodness-of-fit models}

The parameters of four sorption models; GAB, Henderson, Oswin, and Halsey models were evaluated using the SPSS com- 

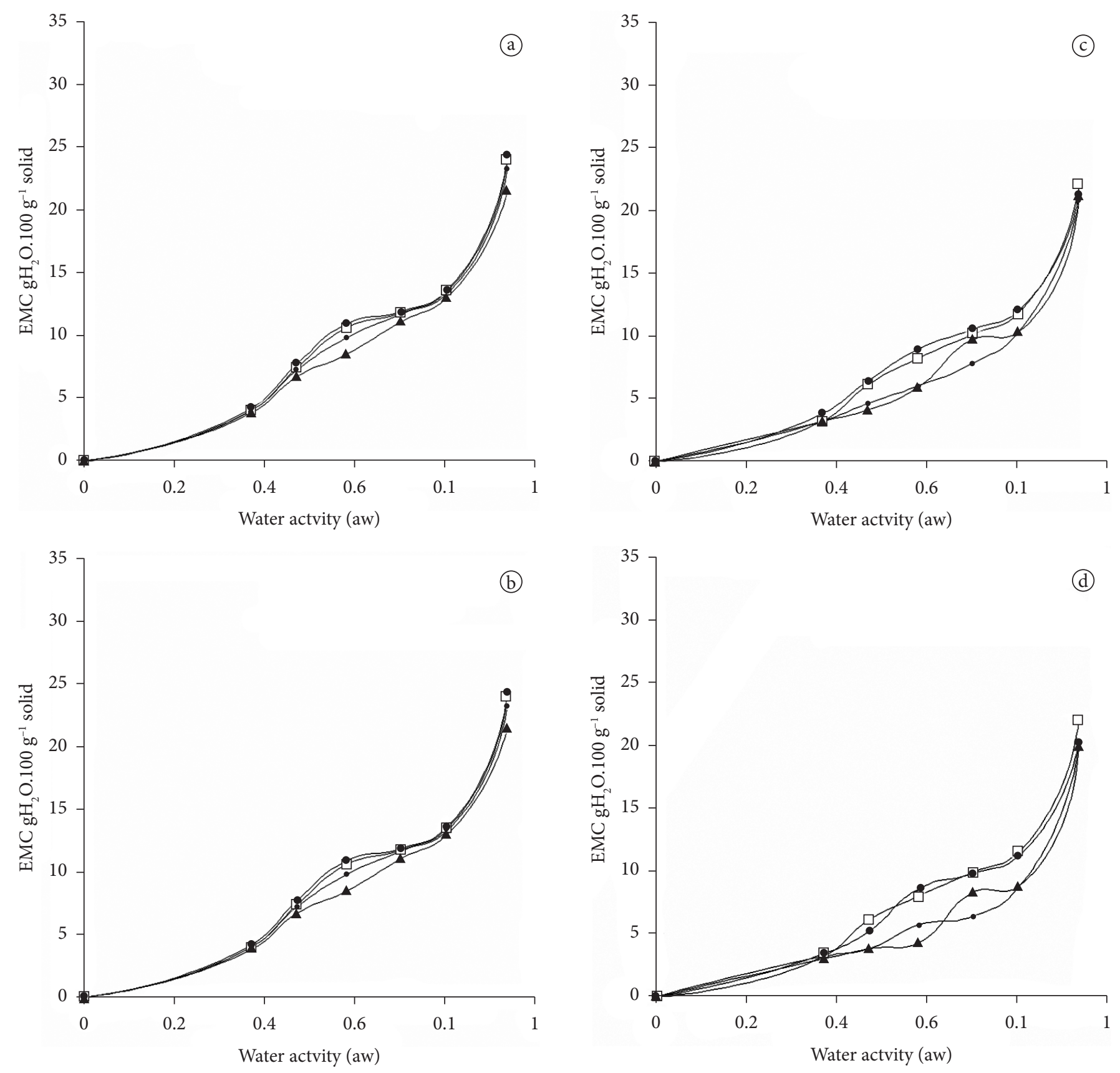

$\begin{array}{|ll|}\rightarrow \rightarrow \text { Peeled Ginger Slice (PGS) } & \rightarrow \text { Peeled-Blanched Ginger Slice (PBS) } \\ \rightarrow \square-\text { Unpeeled-Blanched Ginger Slices (UBS) } & \rightarrow \text { Unpeeled Ginger Slice (UGS) }\end{array}$

Figure 1. Moisture sorption isotherm for ginger slices a) $20^{\circ} \mathrm{C}$; b) $30^{\circ} \mathrm{C}$; c) $40{ }^{\circ} \mathrm{C}$; and d) $50{ }^{\circ} \mathrm{C}$.

puter package and are presented in Table 3. The high regression coefficients ranging from 0.939 to 0.990 indicate that the models are adequate for predicting experimental data for moisture adsorption of the ginger slices.

The percentage root mean square of error (\%RMS) was used to evaluate the goodness-of-fit of each model (Table 4). This parameter was used in the literature to evaluate the goodness-of-fit of different sorption models as applied to experimental data (ARIAHU; KAZE; ACHEM, 2006; MOK; HETTIARACHCHY, 1990; AGUERRE; SUAREZ; VIOLLAZ, 1989). The different models yielded different \%RMS. The Henderson equation predicted the isotherms with the lowest \%RMS. Therefore, this model describes better the adsorption data (WANG; BRENNAN, 1991). Other researchers such as 
Ariahu et al. (2006), Singh and Ojha (1974) tested the validity of Henderson equation for tropical fresh water crayfish, milled nuts, and dried pepper, respectively, and good correlations were found. GAB, Oswin, and Halsey models followed the Henderson model in that order.

\subsection{Monolayer moisture content}

The GAB model was used to estimate the monolayer moisture content (Table 3). The monolayer moisture content represents the moisture of a material when its entire surface is covered with an unimolecular moisture layer. It is the moisture content for the maximum shelf stability. The monolayer moisture generally decreased with temperature for all samples. For the temperatures of 20 and $50^{\circ} \mathrm{C}$, the monolayer of PGS decreased from $5.209 \mathrm{gH}_{2} \mathrm{O} .100 \mathrm{~g}^{-1}$ solid to $1.885 \mathrm{gH}_{2} \mathrm{O} .100 \mathrm{~g} \mathrm{~g}^{-1}$ solid. That of PBS decreased from $6.301 \mathrm{gH}_{2} \mathrm{O} .100 \mathrm{~g}^{-1}$ solid to $2.011 \mathrm{gH}_{2} \mathrm{O} .100 \mathrm{~g}^{-1}$ solid and UBS from $5.066 \mathrm{gH}_{2} \mathrm{O} .100 \mathrm{~g}^{-1}$ solid to $3.691 \mathrm{gH}_{2} \mathrm{O} .100 \mathrm{~g}^{-1}$ solid. The monolayer moisture content of UGS did not show a significant decrease with temperature. The decrease in monolayer moisture with temperature observed in this work was in agreement with Ariahu et al. (2006) for fresh water crayfish, Alakali (2004) for mango slices, and Iglesias and Chirife (IGLESIAS; CHIRIFE, 1976) for some food products. According to those authors, this may be due to the reduction in the number of active sites for water binding because of the physical and chemical changes in the product induced by temperature. Also according to Palipane and Driscoll (1992), another possibility could be because with an increase in the temperature the water molecules get activated, due to increase in their energy level, causing them to become less stable and to break away from the water binding sites of the food material thus decreasing the monolayer moisture content. These observations imply that the optimum moisture for shelf stability of ginger slices will be determined in relation to the anticipated temperature of storage.

\subsection{Sorption thermodynamics}

The net heat of adsorption indicates the building energy or the intermolecular forces between the molecules of water and the surface of the sorbent. The net isosteric heat estimates the minimum amount of heat required to remove or add a given amount of water (RIZVI, 1995; AGUERRE; SUAREZ; VIOLLAZ, 1989).

From the Clausius-Clapeyron Equation 6, an increase in temperature will decrease the sorbed moisture (DIOSADY et al., 1996). The relationship between $\ln \left(\mathrm{a}_{\mathrm{w}}\right)$ and inverse absolute temperature $(1 / \mathrm{T})$ at constant moisture content is presented in Figure 2. The isosteres were straight lines in agreement with Ariahu et al. (2006)

Table 4. Percent root mean square of error (\%RMS) of sorption isotherm models for ginger slices.

\begin{tabular}{ccrrrr}
\hline Pre-treatment & Temperature & \multicolumn{4}{c}{ \%RMS } \\
\cline { 2 - 5 }$\left({ }^{\circ} \mathrm{C}\right)$ & GAB & Henderson & Oswin & Halsey \\
\hline PGS & 20 & 14.24 & 12.05 & 11.99 & 17.54 \\
& 30 & 12.25 & 6.19 & 16.24 & 21.02 \\
& 40 & 7.64 & 9.05 & 15.62 & 10.45 \\
& 50 & 13.75 & 11.83 & 12.75 & 10.43 \\
UGS & 20 & 21.37 & 13.63 & 20.56 & 24.57 \\
& 30 & 14.80 & 10.78 & 16.52 & 20.53 \\
& 40 & 12.56 & 10.07 & 17.31 & 21.43 \\
& 50 & 12.72 & 10.76 & 19.09 & 23.61 \\
PBS & 20 & 15.96 & 17.41 & 20.45 & 33.72 \\
& 30 & 10.40 & 6.86 & 16.52 & 19.92 \\
& 40 & 11.87 & 8.68 & 17.31 & 17.62 \\
& 50 & 13.97 & 17.99 & 19.09 & 13.22 \\
UBS & 20 & 17.14 & 14.17 & 21.69 & 25.88 \\
& 30 & 18.28 & 14.58 & 22.48 & 26.92 \\
& 40 & 16.13 & 11.91 & 24.79 & 25.81 \\
& 50 & 16.74 & 11.61 & 19.35 & 24.11 \\
\hline
\end{tabular}

Table 3. Isotherm model parameters and derivatives for ginger slices ${ }^{\star}$.

\begin{tabular}{|c|c|c|c|c|c|c|c|c|c|c|c|c|c|c|}
\hline Pre-treatment & Temperature $\left({ }^{\circ} \mathrm{C}\right)$ & \multicolumn{4}{|c|}{ GAB model parameters } & \multicolumn{3}{|c|}{$\begin{array}{l}\text { Henderson model } \\
\text { parameters }\end{array}$} & \multicolumn{3}{|c|}{$\begin{array}{c}\text { Oswin model } \\
\text { parameters }\end{array}$} & \multicolumn{3}{|c|}{$\begin{array}{c}\text { Halsey model } \\
\text { parameters }\end{array}$} \\
\hline \multirow[t]{3}{*}{ PGS } & 20 & 5.276 & 0.834 & 5.207 & 0.977 & 14.90 & 1.19 & 0.98 & 7.53 & 0.42 & 0.97 & 51.48 & 2.12 & 0.96 \\
\hline & 40 & 26.950 & 0.928 & 2.608 & 0.993 & 5.52 & 0.92 & 0.98 & 4.78 & 0.53 & 0.99 & 10.26 & 1.68 & 0.99 \\
\hline & 50 & 22.940 & 0.962 & 1.885 & 0.957 & 3.81 & 0.81 & 0.92 & 3.69 & 0.60 & 0.96 & 5.22 & 1.51 & 0.96 \\
\hline \multirow{2}{*}{ UGS } & 40 & 6.003 & 0.842 & 4.557 & 0.979 & 13.03 & 1.19 & 0.98 & 6.81 & 0.42 & 0.98 & 40.70 & 2.10 & 0.97 \\
\hline & 50 & 4.364 & 0.844 & 4.404 & 0.976 & 10.48 & 1.13 & 0.98 & 6.24 & 0.44 & 0.97 & 29.02 & 2.02 & 0.96 \\
\hline \multirow[t]{3}{*}{ PBS } & 20 & 2.400 & 0.789 & 6.301 & 0.984 & 12.71 & 1.16 & 0.99 & 6.98 & 0.43 & 0.96 & 41.53 & 2.08 & 0.95 \\
\hline & 30 & 5.103 & 0.880 & 3.691 & 0.982 & 7.78 & 1.02 & 0.99 & 5.64 & 0.48 & 0.98 & 17.77 & 1.86 & 0.98 \\
\hline & 40 & 7.706 & 0.914 & 2.938 & 0.969 & 5.85 & 0.93 & 0.97 & 4.94 & 0.52 & 0.98 & 11.04 & 1.70 & 0.97 \\
\hline UBS & 50 & 8.685 & 0.886 & 3.691 & 0.978 & 9.06 & 1.06 & 0.98 & 6.11 & 0.47 & 0.94 & 22.47 & 1.58 & 0.98 \\
\hline
\end{tabular}

\footnotetext{
${ }^{\star}$ All parameters have their usual significance.
} 
and Moschair and Fardin (1986). The regression parameters by least square linear analysis are presented in Table 5 with high $\mathrm{R}^{2}$ values. The high $\mathrm{R}^{2}$ values indicate the validity of the ClausiusClapeyron equation in describing the adsorption data of ginger slices. The net isosteric heats were derived from the slope of the plots of $\ln \left(a_{w}\right)$ versus $1 / T$.

The variation of the net isosteric heat with the moisture content of the ginger slices is presented in Figure 3. Figure 3 shows that the isosteric heat decreased with moisture content approaching the asymptotic value or the latent heat of vaporization of pure water $\left(\Delta \mathrm{H}_{\mathrm{st}}=0\right)$. This trend was observed by Ariahu et al. (2006) and Labuza et al. (1985). Therefore, the heat evolved during adsorption of the first few layers of the water molecules was substantially higher than the heat of condensation of pure water. This is probably due to strong bonds between the
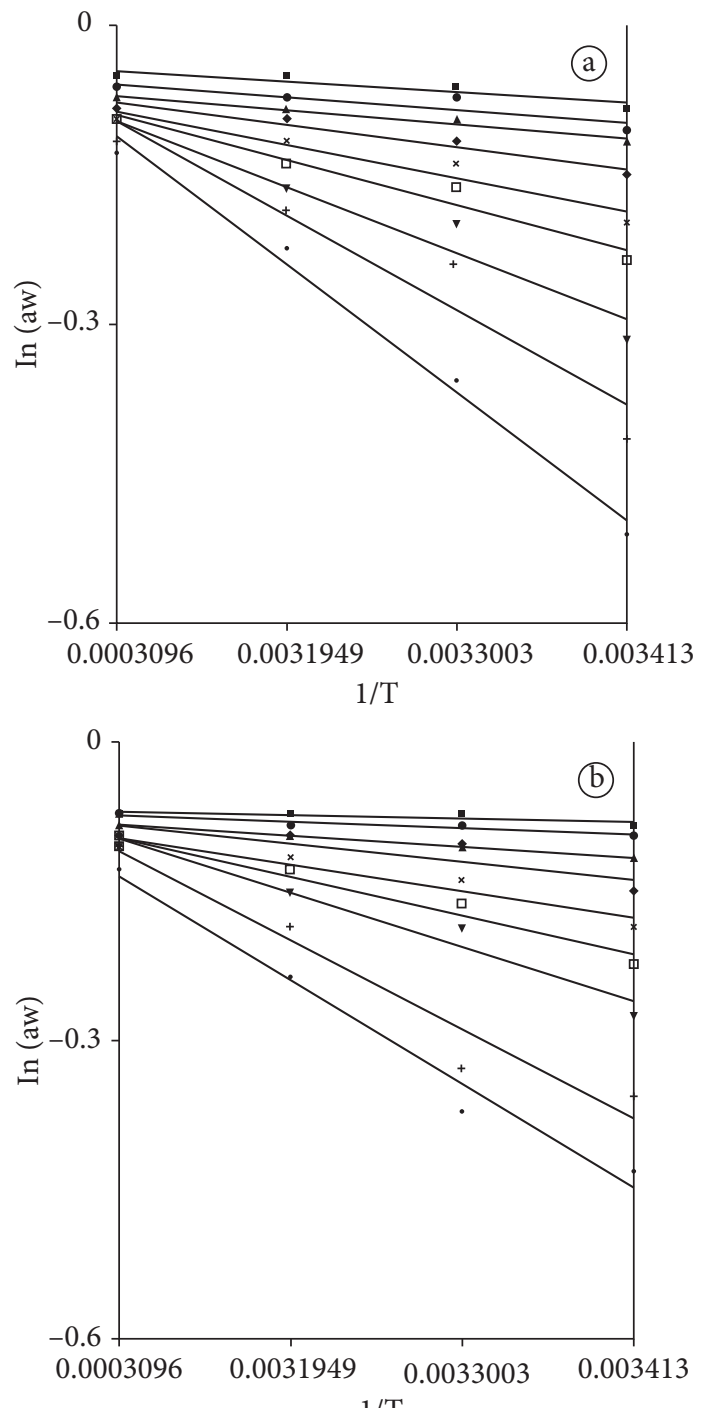

water molecules and the hydrophilic group of food solid. The decrease in the isosteric heat with sorbed water can be quantitatively explained by considering that initially sorption occurs at the most active available sites giving rise to high interaction energy. As these sites become more occupied, sorption occurs at the less available sites, giving rise to lower heat of sorption (ARIAHU; KAZE; ACHEM, 2006; IGLESIAS; CHIRIFE, 1982). According to McLaren and Rowen (1951), the chemisorption polar group could be responsible for the higher sorption heat at very low moisture content. Kapsalis (1981) observed that since thermodynamic quantities are derived from the application of Clausius-Clapeyron equation, anything that affects the sorption isotherms such as the sample prehistory (various pretreatments, blanching, freezing, and drying) would affect them. Consequently, the isosteric heat of PGS was higher, followed by PBS, UGS, and UBS in that order (Figure 3).
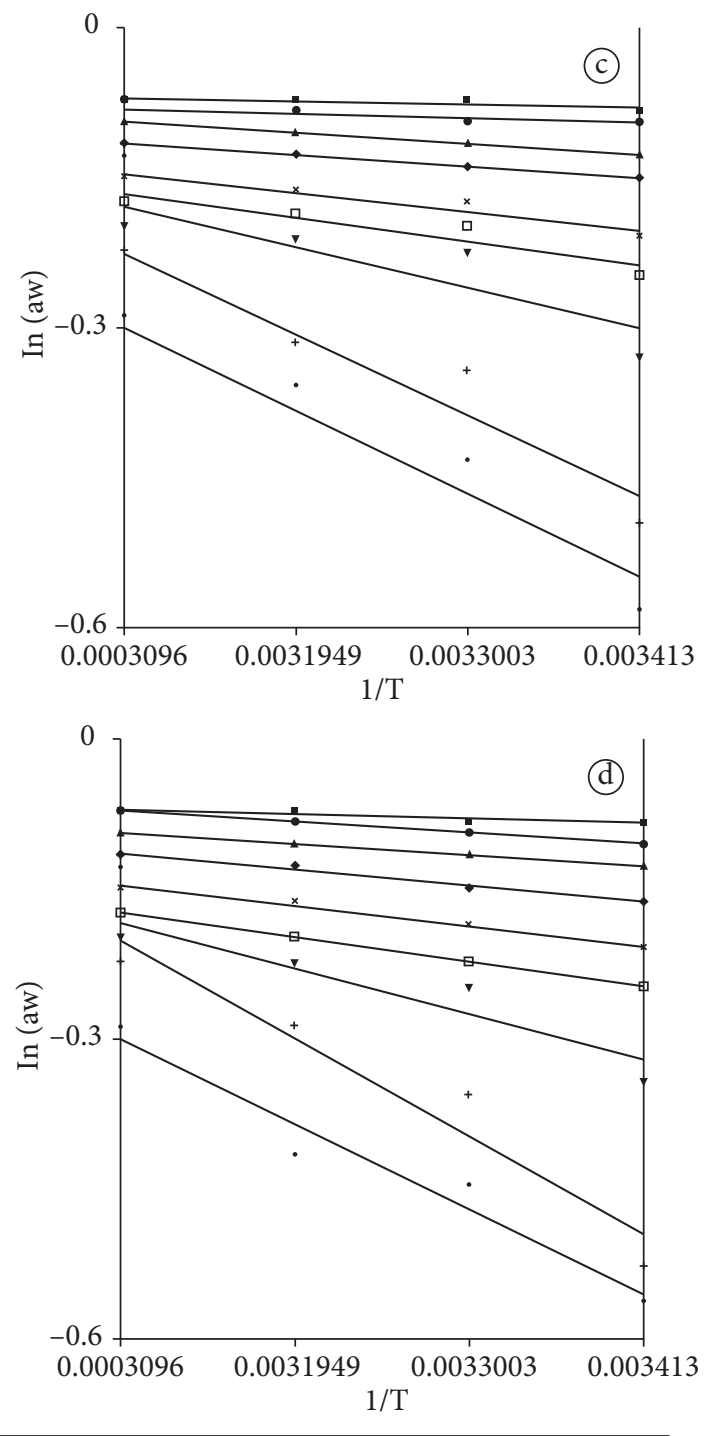

$-10 \% \mathrm{mc}+13 \% \mathrm{mc}+16 \% \mathrm{mc} \cdot 20 \% \mathrm{mc}+11 \% \mathrm{mc} * 14 \% \mathrm{mc}+18 \% \mathrm{mc}-22 \% \mathrm{mc}+22 \% \mathrm{mc}$

Figure 2. Plot of $\ln \left(\mathrm{a}_{\mathrm{w}}\right)$ versus $1 / \mathrm{T}$ for a) peeled ginger slides; b) peeled-blanched ginger slides; c) unpeeled ginger slides; and d) unpeeledblanched ginger slides. 
Table 5. Regression parameters of the relationship between $\ln \left(\mathrm{a}_{\mathrm{w}}\right)$ versus $1 / \mathrm{T}$.

\begin{tabular}{|c|c|c|c|c|c|c|c|c|c|c|}
\hline \multirow[t]{2}{*}{ Pre-treatment } & \multirow{2}{*}{$\begin{array}{l}\text { Regression } \\
\text { parameters }\end{array}$} & \multicolumn{9}{|c|}{ Moisture content ( $\mathrm{g} \mathrm{H}_{2} \mathrm{O} .100 \mathrm{~g}^{-1}$ solid) } \\
\hline & & 10 & 11 & 12 & 13 & 14 & 16 & 18 & 20 & 22 \\
\hline \multirow[t]{4}{*}{ PGS } & $\mathrm{n}$ & 4 & 4 & 4 & 4 & 4 & 4 & 4 & 4 & 4 \\
\hline & A & 3.656 & 2.694 & 1.858 & 1.230 & 0.900 & 0.584 & 0.350 & 0.328 & 0.271 \\
\hline & B & -1216.6 & -901.9 & -631.7 & -425.01 & -319.27 & -213.8 & -136.8 & -124.8 & -102.4 \\
\hline & $\Delta \mathrm{H}_{\mathrm{st}}$ & 10.113 & 7.498 & 5.252 & 3.533 & 2.654 & 1.778 & 1.137 & 1.038 & 0.851 \\
\hline \multirow{3}{*}{ UGS } & A & 2.196 & 2.695 & 1.167 & 0.549 & 0.451 & 0.356 & 0.233 & 0.247 & 0.055 \\
\hline & B & -807.2 & -935.8 & -437.0 & -233.7 & -193.3 & -152.2 & -105.7 & -103.4 & -40.9 \\
\hline & $\Delta \mathrm{H}_{\mathrm{st}}$ & 6.711 & 7.780 & 3.633 & 1.939 & 1.607 & 1.265 & 0.876 & 0.860 & 0.340 \\
\hline \multirow[t]{2}{*}{ PBS } & $\mathrm{n}$ & 4 & 4 & 4 & 4 & 4 & 4 & 4 & 4 & 4 \\
\hline & $\mathrm{R}^{2}$ & 0.973 & 0.939 & 0.967 & 0.964 & 0.930 & 0.779 & 0.999 & 0.670 & 0.626 \\
\hline \multirow[t]{5}{*}{ UBS } & $\mathrm{n}$ & 4 & 4 & 4 & 4 & 4 & 4 & 4 & 4 & 4 \\
\hline & $\mathrm{R}^{2}$ & 0.919 & 0.929 & 0.789 & 0.882 & 0.924 & 0.999 & 0.999 & 0.799 & 0.626 \\
\hline & A & 2.140 & 2.139 & 1.016 & 1.527 & 0.419 & 0.218 & 0.233 & 0.046 & 0.027 \\
\hline & B & -790.6 & -764.5 & -386.5 & -224.1 & -182.7 & -108.1 & -105.7 & -41.33 & -31.34 \\
\hline & $\Delta \mathrm{H}_{\mathrm{st}}$ & 6.573 & 6.356 & 3.213 & 1.863 & 1.519 & 0.904 & 0.878 & 0.344 & 0.261 \\
\hline
\end{tabular}

$\mathrm{n}=$ number of observations; $\mathrm{R}^{2}=$ regression coefficients; $\mathrm{A}=$ intercept; $\mathrm{B}=$ gradient; $\Delta \mathrm{H}_{\mathrm{st}}=$ isosteric heat of sorption. Latent heat of vaporization/condensation of pure water $=4.2 \mathrm{KJ}$.

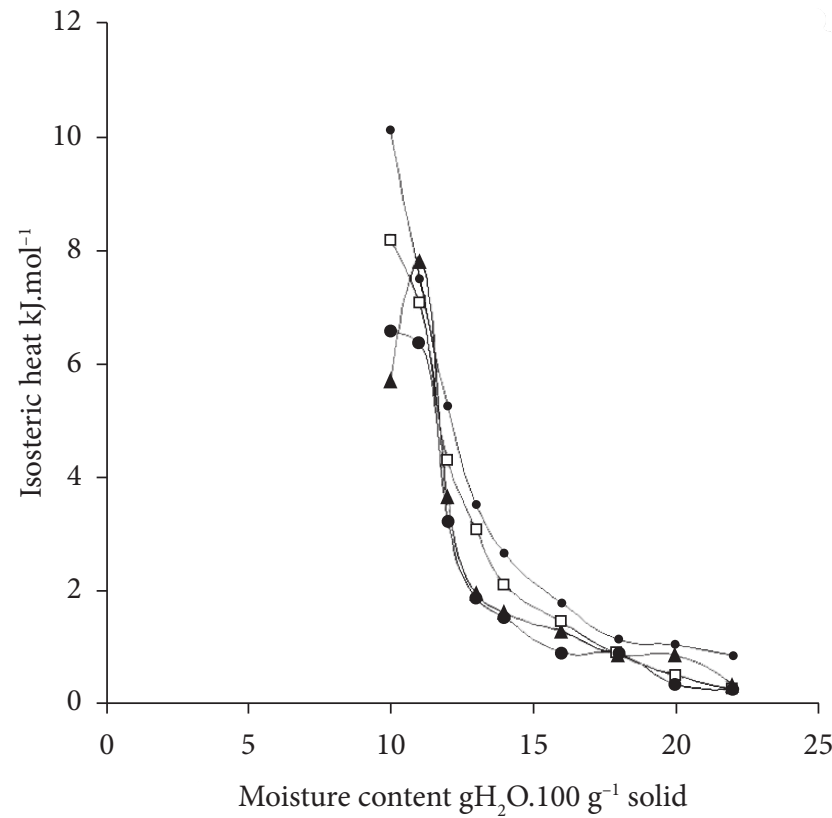

$\multimap$ Peeled Ginger Slice (PGS)
— Peeled-Blanched Ginger Slice (PBS)
$\multimap-$ Unpeeled Ginger Slice (UGS)
$\rightarrow-$ Unpeeled-Blanched Ginger Slices (UBS)

Figure 3. Isosteric heat versus moisture content for ginger slices.

The regression parameters of the plot of the net isosteric heat $\left(\ln \Delta \mathrm{H}_{\mathrm{st}}\right)$ against the moisture content (M), based on Tsa- mi et al. (1990) Equation (7), is presented in Table 6. This Table shows that the isosteric heat of the first molecule $\left(\mathrm{H}_{\mathrm{o}}\right)$ of the unpeeled samples were generally higher than the peeled ones. This result indicates that drying peeled ginger is relatively easier drying unpeeled ginger. This finding is in agreement with the report of Alakali and Satimehin (2004) for the drying of ginger slices. On the contrary, the characteristic moisture content $\left(\mathrm{M}_{\mathrm{ch}}\right)$ of the peeled samples was generally higher than the unpeeled ones. This further reveals that less energy would be needed to dry the peeled than the unpeeled ginger slices.

The entropy of sorption was determined from the intercept of the linearized form of Equation 10, and it is shown in Figure 4. It increased with moisture content. In the moisture content range of 10 to $22 \mathrm{~g} \mathrm{H}_{2} \mathrm{O} .100 \mathrm{~g}^{-1}$ solid, the entropy of sorption increased from -0.03 to $-0.0023 \mathrm{gH}_{2} \mathrm{O} .100 \mathrm{~g}^{-1}$ solid for PGS, -0.018 to $-0.001 \mathrm{gH}_{2} \mathrm{O} .100 \mathrm{~g}^{-1}$ solid for UGS, -0.023 to $-0.0002 \mathrm{gH}_{2} \mathrm{O} .100 \mathrm{~g}^{-1}$ solid for PBS, and -0.018 to $-0.0002 \mathrm{gH}_{2} \mathrm{O} .100 \mathrm{~g}^{-1}$ solid for UBS. This trend was reported by Bethelhiem et al. (1970), Loong et al. (1995), and Ariahu et al. (2006) for swelling biopolymers, freeze dried blueberries, and tropical fresh water crayfish respectively. According to the authors, as moisture content increases, the material swells up opening up new higher energy sites for water to bind. The water molecules also become more mobile with higher degree of freedom leading to higher entropy of sorption. At lower moisture contents, however, the water molecules become more tightly bound by physical and chemosorption forces leading to loss of degree of freedom and decreased entropy. 
Table 6. Parameters of the Tsami equation for ginger slices.

\begin{tabular}{lcccc}
\hline Parameters & PGS & UGS & PBS & UBS \\
\hline $\mathrm{N}$ & 9 & 9 & 9 & 9 \\
$\mathrm{R}^{2}$ & 0.940 & 0.882 & 0.896 & 0.9544 \\
Intercept & 4.1366 & 4.2455 & 4.1256 & 4.4583 \\
$\Delta \mathrm{H}_{\mathrm{o}}$ & 62.589 & 69.791 & 61.905 & 86.360 \\
Gradient & -0.2090 & -0.2395 & -0.2232 & -0.2707 \\
$\mathrm{M}_{\mathrm{ch}}$ & 4.785 & 4.175 & 4.480 & 3.694 \\
\hline
\end{tabular}

$\mathrm{n}=$ number of observations; $\mathrm{R}^{2}=$ regression coefficients; $\Delta \mathrm{H}_{\mathrm{o}}=$ isosteric heat of the first molecule of water; and $\mathrm{M}_{\mathrm{ch}}=$ characteristic moisture content.

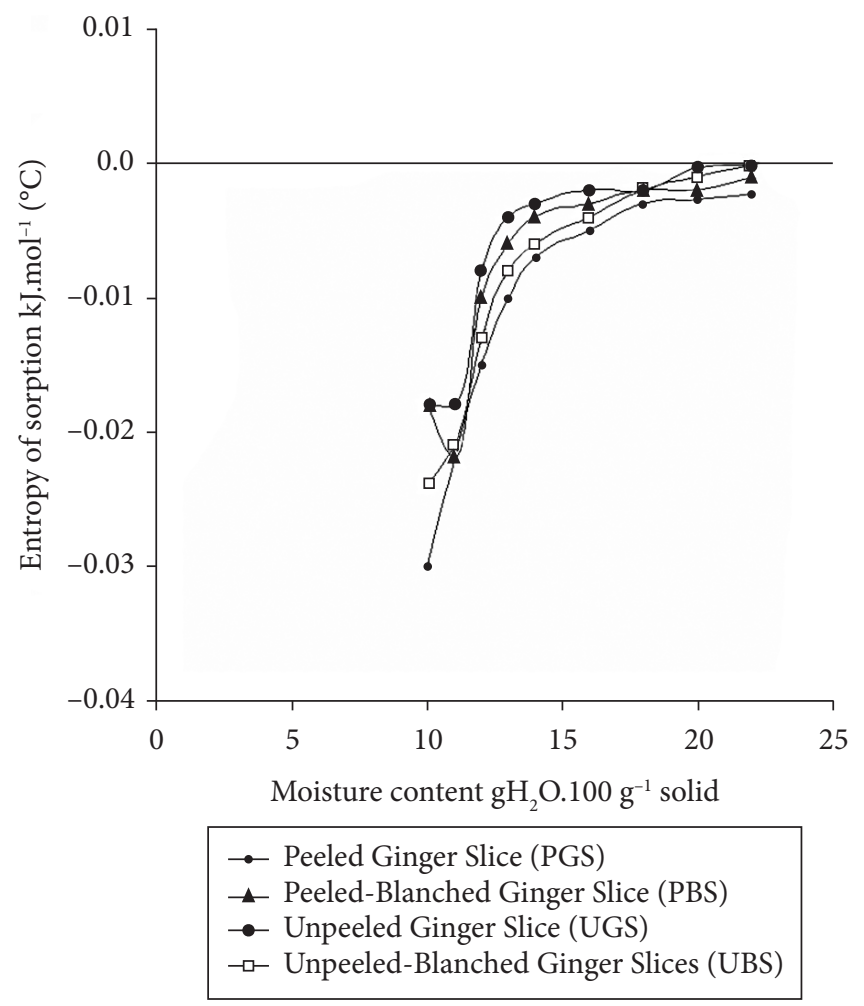

Figure 4. Entropy of sorption for ginger slices.

\section{Conclusions}

The following conclusions can be drawn from the study:

a) The equilibrium moisture content of the dried ginger slices increased directly proportionally to water activity and inversely proportionally to temperature;

b) Henderson model made more accurate predictions about the sorption data;

c) Unpeeled ginger slices were less hygroscopic than the peeled ones;

d) Blanched ginger slices had the lowest EMC and therefore are more shelf stable; and

e) The isosteric heat of sorption decreased while the entropy of sorption increased with an increase in moisture content.

\section{References}

Agricultural Extension, Research Liaison and Training - AERLS. Ginger production. Umudike, Nigeria: National Root Crop Research Institute - NRCRI, 1987. p. 1-5. (Bulletin).

AGUERRE, R. J.; SUAREZ, C.; VIOLLAZ, P. E. New BET type multilayer sorption isotherms. Part II. Modelling water sorption in foods. Aguerre R. J.; Suarez C.; Viollaz P. E. New BET type multilayer sorption isotherms. Part II: Modelling water sorption in foods. Lebensmittel-Wissenschaft und Technologie, v. 22, p. 192-195, 1989.

ALAKALI, J. S.; SATIMEHIN A. A. Drying kinetics of ginger. Nigerian Food Journal, v. 22, p. 105-111, 2004.

ARIAHU, C. C.; KAZE, S. A.; ACHEM, C. D. Moisture sorption characteristics of tropical fresh water crayfish (Procambarus clarkia). Journal of Food Engineering, v. 75, p. 355-363, 2006.

BETHELHIEM, F. A.; BLOCK, A.; KAUFMANN, I. J. Heat of water vapour sorption in biopolymers. Biopolymers, v. 9, n. 3, p. 1531-1538, 1970.

BIZOT, H. Using the GAB model to construct sorption isotherms. In: JOWITT et al (Eds.) Physical properties of foods. New York: [s.n], 1983. p. 43-54.

CENKOWSKI, S.; JAYAS, D. S.; HAO, D. Latent heat of vaporization for selected foods and crops. Canadian Agricultural Engineering, v. 34, n. 3, p. 281-284, 1992.

CHEN, C.; LAI, C. The study on the application equation for the vaporization heat of water in agricultural products. Journal of Agricultural Research, v. 39, n. 1, p. 377-389, 1990.

DIOSADY, L. C. et al. Moisture sorption isotherms of canola meals and application to packaging. Journal of Food Science, v. 61, n. 2, p. 204-208, 1996.

EZEIKE, G. O. I. Hygroscopic characteristics of unshelled egusi (melon) seeds. International Journal of Food Science and Technology, v. 23, n. 3, p. 511-519, 1988.

GALLAGHER, G. L. A method of determining latent heat of agricultural crops. Agricultural Engineering, v. 32, n. 3, p. 34-38, 1951.

HALSEY, G. Physical adsorption on non uniform surface. Journal of Chemical Physics, v. 16, p. 931-937, 1948.

HENDERSON, S. M. Basic concepts of equilibrium moisture. Agricultural Engineering, v. 33, n. 3, p. 29-33, 1952.

IGLESIAS, H. A.; CHIRIFE, J. S. C. On the local isotherm concept and models of moisture binding in food products. Journal of Agriculture and Food Chemistry, v. 24, n. 6, p. 77, 1976.

IGLESIAS, H. A.; CHIRIFE, J. S. C. On the local isotherm concept and models of moisture binding in food products. Journal of Agriculture and Food Chemistry, v. 24, n. 6, p. 77-82, 1982.

KAPSALIS, J. G. Moisture sorption hystereses. In: ROCKLAND, L. B.; STEWART, G. F. (Eds.). Water influence on food quality. NewYork: Academic Press, 1981. p. 143-177.

KIRANOUDIS, C. T. et al. Equilibrium moisture content and heat of desorption of some vegetable. Journal of Food Engineering, v. 20, n. 6, p. 55-74, 1993.

KOCHHAR, A. Tropical crops. A textbook of economic botany. London: McMillan Press, 1981. p. 268-270.

LABUZA, T. P.; KAANENE, A.; CHEN, J. Y. Effect of temperature on the moisture sorption and water activity shift of two dehydrated foods. Journal of Food Science, v. 50, n. 11, p. 382-391, 1985. 
LOONG, T. L.; JUMING, T.; JIANSHAN, H. Moisture sorption characteristics of freeze dried blueberries. Journal of Food Science, v. 6, n. 4, p. 810-819, 1995.

MCLAREN, A. D.; ROWEN, J. W. Sorption of water by proteins and polymers, a review. Journal of Polymer Science, v. 57, p. 289-324, 1951.

MENKOV, M. D.; DURAKOVA, A. G.; KRASTEVA, A. Moisture sorption isotherms of common bean powders at several temperatures. Electronic Journal of Environmental, Agricultural and Food Chemistry, v. 4, n. 2, p. 892-898, 2005.

MOK, C.; HETTIARACHCHY, N. S. Moisture sorption characteristics of ground sunflower nutmeal and its products. Journal of Food Science, v. 55, n. 2, p.786-789, 1990.

MOSCHAIR, S. M.; FARDIN, J. W. Sorption properties of raw huke muscles. Journal of Food Technology, v. 21, n. 4, p. 95-102, 1986.

OSWIN, C. R. The kinetics of packaged life III. The isotherm. Journal of Chemical Industry, v. 65, p. 419-423, 1946.

PALIPANE, K. B.; DRISCOLL, R. H. Moisture sorption characteristics of moshell macadamia nuts. Journal of Food Engineering, v. 18, p. 63-76, 1992.

RIZVI, J. H. Thermodynamic properties of foods. In: RAO, M. A.; RIZVI, S. S. H. (Eds.). Dehydration properties of foods. N.Y.: Marcel Dekker Inc., 1995. p. 223-309.
ROCKLAND, L. B. Water activity and storage. Food Technology, v. 23, p. 1241-1251, 1969.

SATIMEHIN, A. A.; EZEIKE, G. O. I. Moisture desorption characteristics of gelatinized white yam (Dioscorea rotundata, Poir). Nigerian Food Journal, v. 20, p. 58-64, 2002.

SINGH, R. S.; OJHA, T. P. Equilibrium moisture content on groundnut and chilies. Journal of Science of Food and Agriculture, v. 25, n. 5, p. 455-459, 1974.

SPIESS, W. C. T.; WOLF, W. Critical evaluation of methods to determine moisture sorption isotherms. In: ROCKLAND, L. B. (Ed.). Water activity. N.Y.: [s.n], 1986. p. 123.

TSAMI, E. et al. Heat of sorption of water in dried fruits. International Journal of Food Science and Technology, v. 25, n. 6, p. 350-359, 1990.

Van DEN BERG, C. Development of BET like model for sorption of water on foods, theory and relevance. In: SIMATOS, D.; MULTON, J. L. (Ed.). Properties of water in foods. Dordrechts, The Netherlands: Martinus Nijhoff Publishers, 1985. p. 119-131.

WANG, N.; BRENNAN, J. G. Moisture sorption characteristics of potatoes at four temperatures. Journal of Food Engineering, v. 14, n. 7, p. 269-287, 1991.

WEAST, R. C.; ASTLE, M. I. CRC Handbook of Chemistry and Physics. Boca Raton, Florida: CRC Press Inc., 1989. p. 44. 